\title{
A Papyrus-Carrying Scene from the Tomb of Ukhhotep Son of Senbi (B 2) at Meir
}

\author{
Heba I. M. Mahran \\ Minia University
}

\begin{abstract}
Ancient Egyptians made use of every natural aspect in their surroundings and illustrated in their tombs. Papyrus was one of the plants that grew naturally in Egypt across the Nile River. Ancient Egyptians used papyrus in many aspects; the prominent, even in modern times, was as a writing material. They used to collect papyrus from the marshes, stack in piles, and then use the plant after processing in various things. Several scenes depict collecting and carrying papyrus piles while workers are in different positions. This study explains the papyrus carrying scene on walls of the tomb of Ukhhotep son of Senbi (B 2) at Meir. The researcher describes the scene and compares it with similar ones from the old and new kingdoms. This research testifies on the scene's originality, besides the high skill of Meir's local artisan to depict difficult carrying positions and workers distinctive features.
\end{abstract}

Keywords: Papyrus, Papyrus-carrying, Meir, Old Kingdom

\section{Introduction}

Papyrus, Cyperus papyrus, was a very important plant in ancient Egyptians' daily life. It was employed in modelling sandals, basketry, skiffs, writing paper, and sometimes for eating. ${ }^{1}$ Farming papyrus to prepare writing material was under the government control; to maintain quality and to retain the industry secrets. ${ }^{2}$ In modern times, farming papyrus started in 1962 by Eassan Rāgāb. It is farmed in many places to supply tourist needs of painted papyrus sheets. ${ }^{3}$ A number of Old Kingdom tombs' Scenes depict collecting Papyrus; and represent carrying papyrus in a minor icon. ${ }^{4}$ In later periods; this icon appeared less frequent than before. Over than thirty scenes of papyrus carriers were attributed to the Old Kingdom; two from the Middle Kingdom, and other two from the New Kingdom.

\section{Discussion and Results}

Here is a papyrus carrying scene - of specific interest- from the $12^{\text {th }}$ Dynasty tomb of Ukhhotep son of Senbi at Meir (B 2). ${ }^{5}$ The unpainted high relief scene is on the lower part of the northern wall (Fig. 1). It represents a group of six workers carrying bundles of papyrus, while the seventh worker who is supposed to receive the bundles is damaged. Each worker embodies a different motion but in a logical sequence to fulfill the required work. This scene's significance is due to being one of the Middle Kingdom two scenes, and represents carrying papyrus in uncommon pose. ${ }^{6}$ The second scene comes -as well- from Meir, exactly from the $12^{\text {th }}$ Dynasty tomb of Ukhhotep son of Ukhhotep and Mersi (B 4). ${ }^{7}$

Starting from right to left; two workers are tying papyrus stems with ropes and push the bundle with their knees. The right-side man is supporting the bundle with his right arm, and grasping the rope with his left. The other worker is turning his body to the back to tighten the rope knot (Fig.1, first two figures). The workers' facial features reflect seriousness, while their protruding muscles testify on their power. Both figures are naked except from a short length apron to facilitate movement during work. ${ }^{8}$ In modern times, workers carrying heavy stuff usually tie their waists with a cloth to support their backs and protect it from being ripped. This also the case with lifting weights athletes who use a belt to support themselves while lifting weight to protect their backs.

According to the National Strength and Conditioning Association (NSCA), a weight lifting belt helps to lift more weight due to the recoil occurs when the backbone makes interact with the stiff belt. It creates intra-abdominal pressure, strengthens the torso, and protects the backbone while lifting heavy weights. ${ }^{9}$ Pushing knees against the bundle is seen in scenes of carrying papyrus in Saqqara tombs of Ptahhotep (Fig.2), ${ }^{10}$ in the chapel of Ahkethotep ${ }^{11}$, Ihy reused by Idut ${ }^{12}$, Nebkauhor, ${ }^{13}$ Irenkaptah, ${ }^{14}$ Niankhnesut, ${ }^{15}$ and in traces of a scene from the tomb of Hesimen at El Hawawish; the only provincial tomb depicts the motif of tying papyrus. ${ }^{16}$ The workers in these scenes are depicted in symmetrical.

The next worker is carrying his heaviness on back. He is holding the bundle through a rope by his right hand while leaning by the other hand on the ground. Several differences are obvious for the crouching or bending workers of carrying papyrus between Memphis and other provinces. ${ }^{17}$ From the tomb of Ukhhotep son of Ukhhotep and Merci (B 4), on the eastern end of the northern wall near a marsh, are traces of a worker carrying a papyrus bundle on his bent back, while holding or pulling a papyrus stem. ${ }^{18}$ In this course, the scene resembles some of the Old Kingdom scenes combines between papyrus marshes and the carrying workers. ${ }^{19}$

The third person (Fig.1) is totally naked. Nakedness in ancient Egypt was not only associated with poverty, but various types of nude figures appeared in reliefs. Children were represented nude as to signify their innocence. Nudity 
seems to be connected to some careers' conditions; like hot weather, and dirty or wet surroundings. Of these careers; farmers, bakers, potters, and herdsmen, though some of these careers' owners depicted dressed. However, in those cases the workers wearing kilts; lift them up so uncovering their genitals. ${ }^{20}$ Nudity here helps the worker to easily fulfil his career. Examples are known elsewhere depicting nude papyrus carriers (Figs 3-5). ${ }^{21}$

It is noticeable, papyrus bundles are represented with stem lines rather than a package as in the majority of scenes. Such representation appeared in limited tombs; such as the tombs of Kayemnofret, Nebemakhet, Ti, Nefer and Khahy, Werirni, Khunsu, Inti, Hesimin and Puymera. ${ }^{22}$ Another posture from Meir appears in the Sixth Dynasty tomb of Pepyankh: Heneykem (A2), where bending and kneeling figures are featured in symmetrical scale to the standing figure, but lesser in vitality and elegance than the Middle Kingdom Meir figures, the source to the developing of artistic technique of Meir's local art. ${ }^{23}$

From Sheikh Said; the tomb of Werirni displays two postures; a carrier trying to stand up with his load, the other worker is bending his back to carry the bundle. ${ }^{24}$ Although the workers are in activity, neither their expressions nor limbs demonstrate such motivation. The tomb of Ti provides a beautiful example of a worker falling and his mate helps him to rises up again, while another one is supporting the papyrus bundles from behind (Fig.3). ${ }^{25}$ Another beautiful figure of a man crouching under his heaviness is recovered from the tomb of Sendjemib: Inti at Saqqara, he is stretching his arm and leg to balance himself. ${ }^{26}$

A scene from the early New Kingdom tomb of Puyemra (TT 39) represents a man slightly bends his back under a precisely arranged bundle; he seems to hold the bundle by a stick not by a rope as usual. He seems not suffering from his heavy load as he looks like the god Hapi with his abdominal folds (Fig. 4). ${ }^{27}$

Crouching and bending figures of the middle kingdom at Meir are comparable to Memphite examples in modeling figures, and distinctive facial features; yet with stiff expressions. Meanwhile, they are more gorgeous than their Old Kingdom provinces counterparts. The fourth worker in the studied scene is another naked worker bending his back to support his load with both hands in abbreviated shoulder position ( $4^{\text {th }}$ person, fig. 1 ). This is a common posture to handle heavy loads, with lots of alternatives, ${ }^{28}$ as in the tombs of Nebemakhet at Giza, ${ }^{29}$ Nefer and Khahy, ${ }^{30}$ Nebet at Saqqara, ${ }^{31}$ Ptahshepses at Abusir.$^{32}$ Similar postures are extant in the provincial tombs of Werirni at Sheikh Said, Khunes at Zawyet el Mayetin. ${ }^{33}$, Ibi at Deir el Gabrawi, ${ }^{34}$ Kar at El Hawaish, ${ }^{35}$ and a relief now in the Egyptian Museum (CG 1735). ${ }^{36}$

A scene from the tomb of Ukhhotep son of Ukhhotep and Mersi (B 4) depicts the carrier holding his load in a forward-shoulder position, ${ }^{37}$ a relatively difficult posture to control heavy loads. Some examples of such posture occur in Saqqara, in the tombs of Iymery, ${ }^{38}$ and Kapi ${ }^{39}$ in Giza, tomb of Tepemankh at Abusir, ${ }^{40}$ beside samples from the provinces include the tomb of Inti at Deshasheh. ${ }^{41}$

Following the bending figure; are two identical standing workers; with strange haircuts, beards and heavy lips (Fig.1, fifth and sixth persons). Judging from their features, they differ from other papyrus carriers, they seem Nubians. They are holding their weight in unfamiliar painful posture; twisting both arms backwards to hold the bundles. In this case, the common postures are putting one arm around the bundle while holding it against the back line or waist, or holding the bundle with both hands in front, as tombs of Persen, ${ }^{42}$ Ptahhotep, ${ }^{43}$ Nebkauher, ${ }^{44}$ Mehu, ${ }^{45}$ Ihy reused by Idut, ${ }^{46}$ and Ti in Saqqara, ${ }^{47}$ tomb of Kapi at Giza,${ }^{48}$ Werirni at Sheikh Said, Khunnes at Zawyet el Mayetin and Inti at Deshasha.

A rare example of a carrier twisting his arms to hold the bundles on his back stands in Akhethotep tomb in Saqqara (Fig.5). ${ }^{49}$ The carrier is represented with a folded- over shoulder, first appeared with the man holding a basket on the mace head of the scorpion king. ${ }^{50}$ Such posture in carrying objects was familiar in the Middle kingdom tombs of Beni Hassan, however, was lesser in the New Kingdom. ${ }^{51}$ In this scene, the figure is rigid and stiff if compared to Meir figures, where the backbone is stretched against the bundles. The second carrier's figure is depicted with his left arm totally surrounding the load from its middle, while his right arm supports the bundle's top. Most likely, it is the same case in the first figure, which is slightly broken in the middle.

The New Kingdom tomb of Huya at Amarna provides a marshland scene, with traces of unalike posture of papyrus carrier. The carrier holds the bundle on his left shoulder and his right hand supports it. The bundle is bent because of its weight, ${ }^{52}$ a reminder of modern sugar cane carriers in Upper Egypt.

One can expect that carrying papyrus follows collecting it; however, this was not constant. The studied scene of carrying papyrus at Meir was independent, neither collecting scenes nor marshlands are depicted. It is rather preceded by offering bearers and followed by forming boats. ${ }^{53}$ The papyrus probably was used for forming the boat, but unexpectedly the workers are directed to the other way, where the offering bearers are. Perhaps papyrus here is a kind of offerings. Particularly, there are scenes of papyrus carriers among offering bearers, ${ }^{54}$ in the tombs of Mereruka, ${ }^{55}$ and Khewen-wekh at Quesir el Amarna. ${ }^{56}$ Unlike other scenes; Papyrus here is small bundles carried by one hand not like the huge loads. 


\section{Conclusion}

Papyrus carrying scene was common in the Old Kingdom tombs. The theme appeared either alone or accompanied by papyrus marshes or modeling boats and making ropes. Those scenes appeared in many sites; Giza, Saqqara, Abu Șir, besides a number of provincial tombs. In the Middle and New Kingdoms tombs; such themes were rarely depicted. During the new kingdom, religious scenes were prominent. While the majority of the Middle Kingdom findings came from sarcophagi and stelae. The attained scenes through all periods displayed carrying papyrus in variant postures. Some tombs depict large papyrus carrying scenes; thus various postures can be detected in one scene; while others depict only one or two postures. Table 1 details papyrus- carrying postures in relation to Meir studied scene.

Going through the scenes; some postures were not frequently represented, such as pushing the knees to tighten the papyrus bundle, though when occurred enlivened the scene and gave it vitality. The twisted arms posture to carry papyrus is very rare regarding to its difficulty in real life. Carrying papyrus bundles with both hands in front was common, though frontward and condensed postures were attested as well. Crouching figures either of the heaviness or falling down during work were also uncommon. Representing the workers extremely bent under their heaviness was less depicted than those slightly bent. Sometimes, workers were depicted standing and holding the loads on their backs which is difficult. Carrying a bundle on one shoulder, supporting it with both hands has once appeared at Amarna. The most common posture of handling papyrus was on their backs.

Though Meir scene has some identical ones; it gives various vivid postures with rare arm positions. It gives more attention to expressive facial features and illustrates the physical strength a carrier of heavy loads should possess. It provides an image of the distinctive local art school of Meir, where the artisans became efficient and unrestricted to the influence of the traditional Memphite School of art during the Middle Kingdom. As a result they emulated other provincial schools. 
Heba I. M. Mahran

\begin{tabular}{|c|c|c|c|c|c|c|c|c|c|c|c|c|c|c|}
\hline 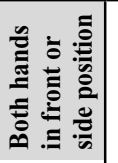 & $x$ & & $x$ & & & & & & $x$ & & $x$ & $x$ & $\times$ & $x$ \\
\hline 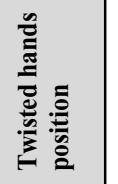 & & & & & & & & & & & $x$ & & & \\
\hline 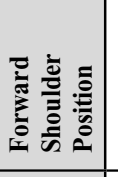 & $x$ & $x$ & $x$ & & & $x$ & $x$ & $x$ & $x$ & $x$ & $x$ & $x$ & $x$ & $\times$ \\
\hline 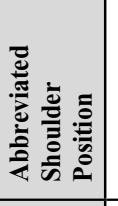 & & & & $x$ & $x$ & & & & $x$ & & $x$ & $x$ & & \\
\hline 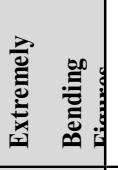 & & & & & & & & $x$ & $x$ & & & $x$ & & \\
\hline 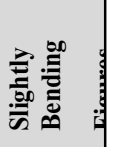 & & $x$ & $x$ & $x$ & $x$ & & $x$ & & $x$ & $x$ & $x$ & $x$ & & $x$ \\
\hline 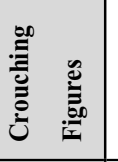 & & $\times$ & & & & & & $x$ & & & & & & \\
\hline 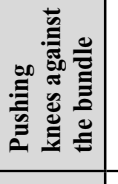 & & & & & & & & & & $x$ & $x$ & $\times$ & & \\
\hline Iั๊ & 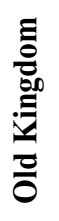 & 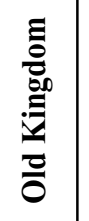 & 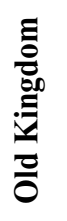 & 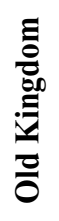 & 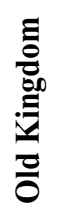 & 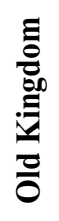 & 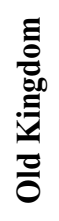 & 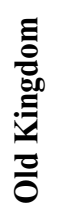 & 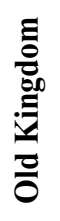 & 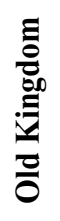 & 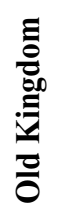 & 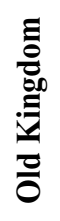 & 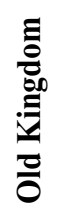 & 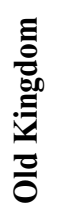 \\
\hline$\stackrel{\Xi}{*}$ & تָ & 존 & 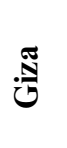 & 丞 & $\begin{array}{l}:= \\
\frac{1}{2}\end{array}$ & : & $\frac{\pi}{\frac{\pi}{\sigma}}$ & $\frac{\pi}{\frac{\pi}{\sigma}}$ & $\frac{\pi}{\frac{\pi}{\sigma}}$ & $\frac{\pi}{\frac{\pi}{\sigma}}$ & $\frac{\pi}{\frac{\pi}{\sigma}}$ & $\frac{\pi}{\frac{\pi}{5}}$ & $\frac{\pi}{\frac{\pi}{\sigma}}$ & \\
\hline ह气 है & 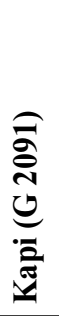 & 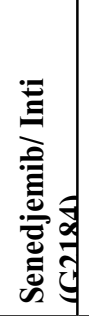 & 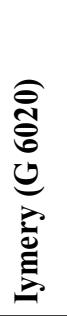 & 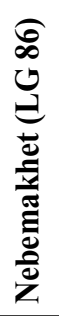 & 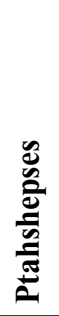 & 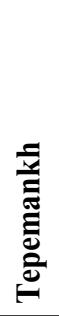 & 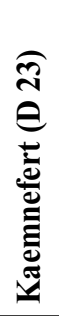 & 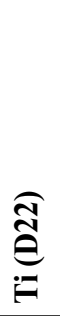 & 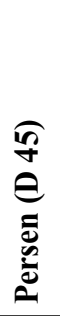 & 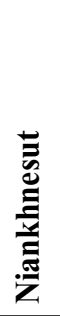 & 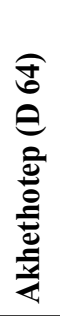 & 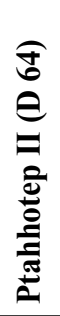 & 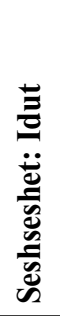 & E \\
\hline
\end{tabular}




\begin{tabular}{|c|c|c|c|c|c|c|c|c|c|c|c|c|c|c|c|}
\hline 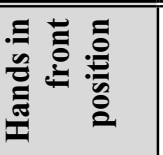 & & $x$ & & & & $x$ & $x$ & $x$ & & & & & & $x$ & \\
\hline 总气气气言 & & & & & & & & & & & & & $x$ & & \\
\hline 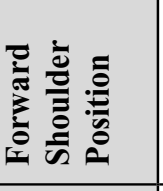 & & & $x$ & & $x$ & & $x$ & & & & & & & & $x$ \\
\hline 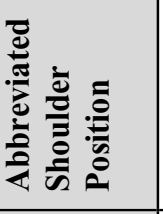 & $x$ & & $x$ & & $x$ & $x$ & $x$ & $x$ & & $x$ & & $x$ & & & \\
\hline 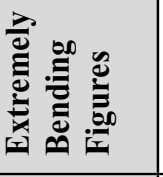 & & & & & $x$ & & $x$ & & $x$ & & & & $x$ & $x$ & \\
\hline 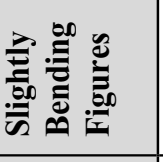 & $x$ & & $x$ & $x$ & $x$ & & $x$ & $x$ & & & & $x$ & & & $x$ \\
\hline 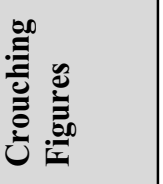 & & & & & & & $x$ & & $x$ & & & & $x$ & & \\
\hline 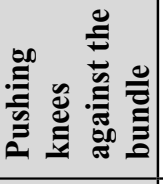 & & $x$ & & & & & & & & & $x$ & & $x$ & & \\
\hline 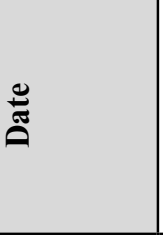 & 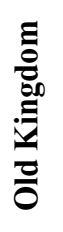 & 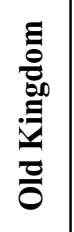 & 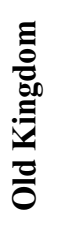 & 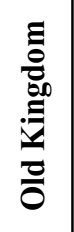 & $\begin{array}{l}\Xi \\
\vdots \\
\vdots \\
\vdots \\
0 \\
0 \\
0 \\
0\end{array}$ & 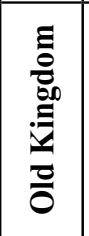 & 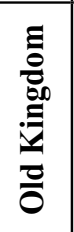 & 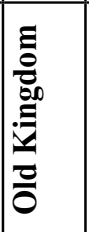 & 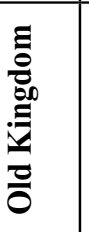 & 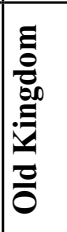 & 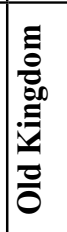 & 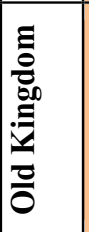 & 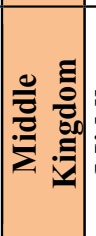 & 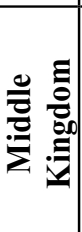 & 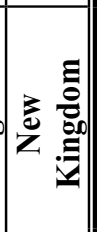 \\
\hline 部 & & $\begin{array}{c}\frac{\pi}{\tilde{E}} \\
\frac{\sigma}{\sigma} \\
\tilde{n}\end{array}$ & & $\frac{\widetilde{T}}{\tilde{E}}$ & 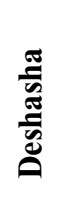 & 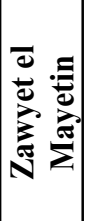 & 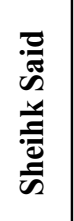 & 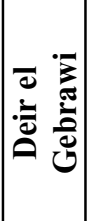 & $\sum_{\bar{z}}$ & 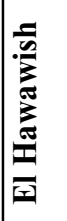 & 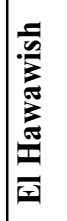 & 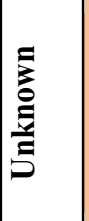 & 产 & $\sum_{\bar{z}}$ & 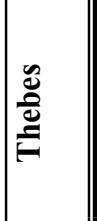 \\
\hline है & $\begin{array}{l}\vec{\Phi} \\
\overline{0} \\
\overline{0}\end{array}$ & 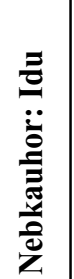 & 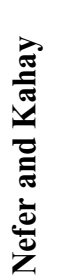 & 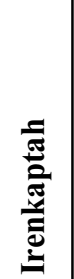 & $\ddot{\Xi}$ & 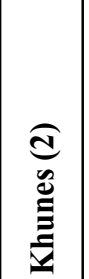 & 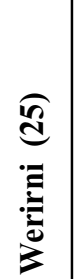 & 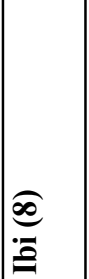 & 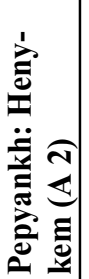 & 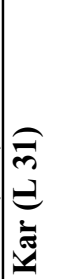 & 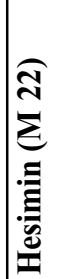 & 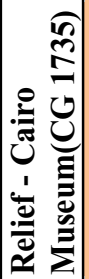 & 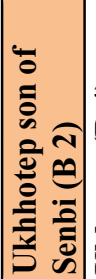 & 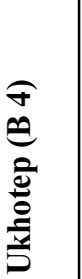 & 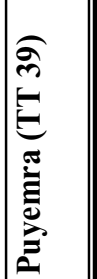 \\
\hline
\end{tabular}




\section{Figures}

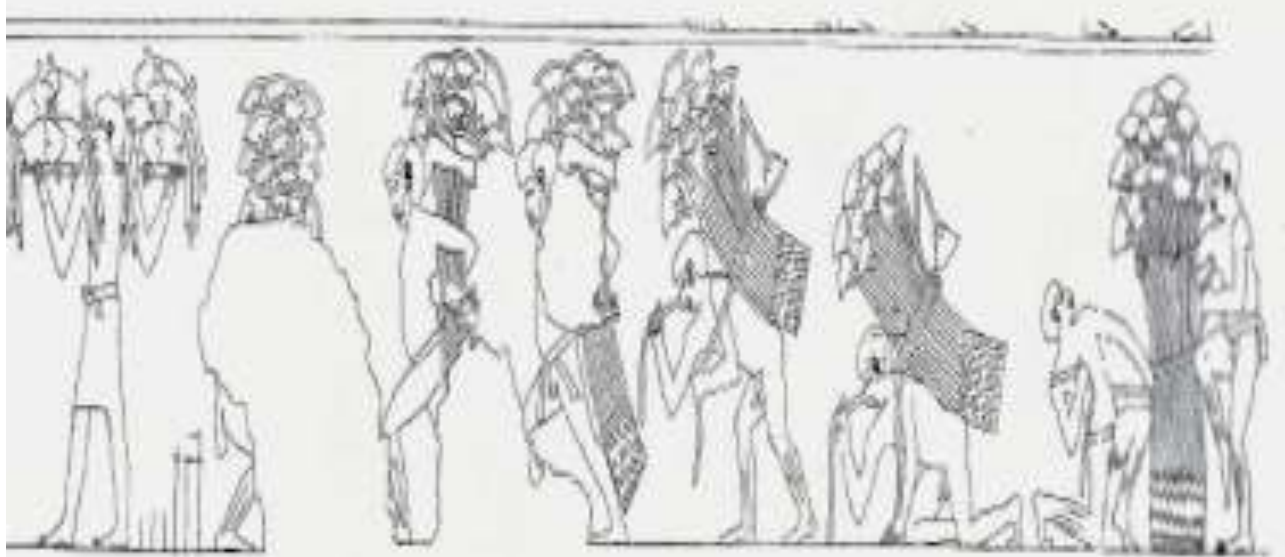

Fig. 1: Papyrus Carriers-Tomb of Ukhhotep son of Senbi (B, No.3) (Blackman, Meir II, pls. III-IV).

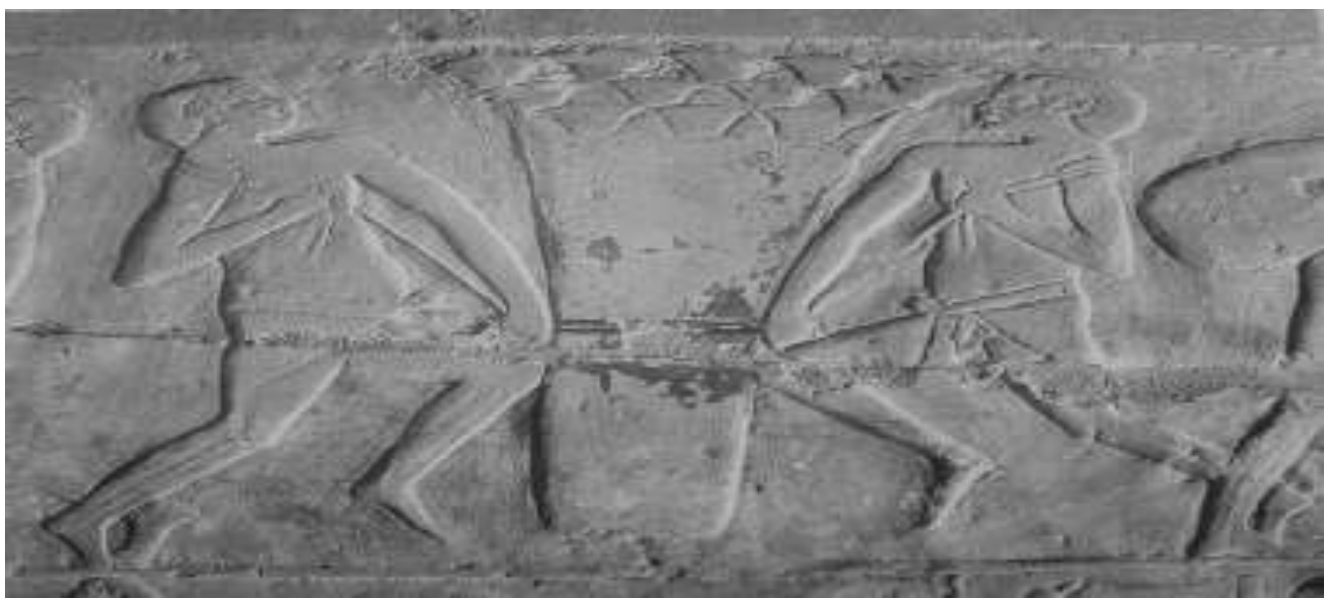

Fig. 2: Two workers tying Papyrus, tomb of Ptahhotep, $5^{\text {th }}$ Dynasty. (Harpur/Scremin, Chapel of Ptahotep, fig.115.

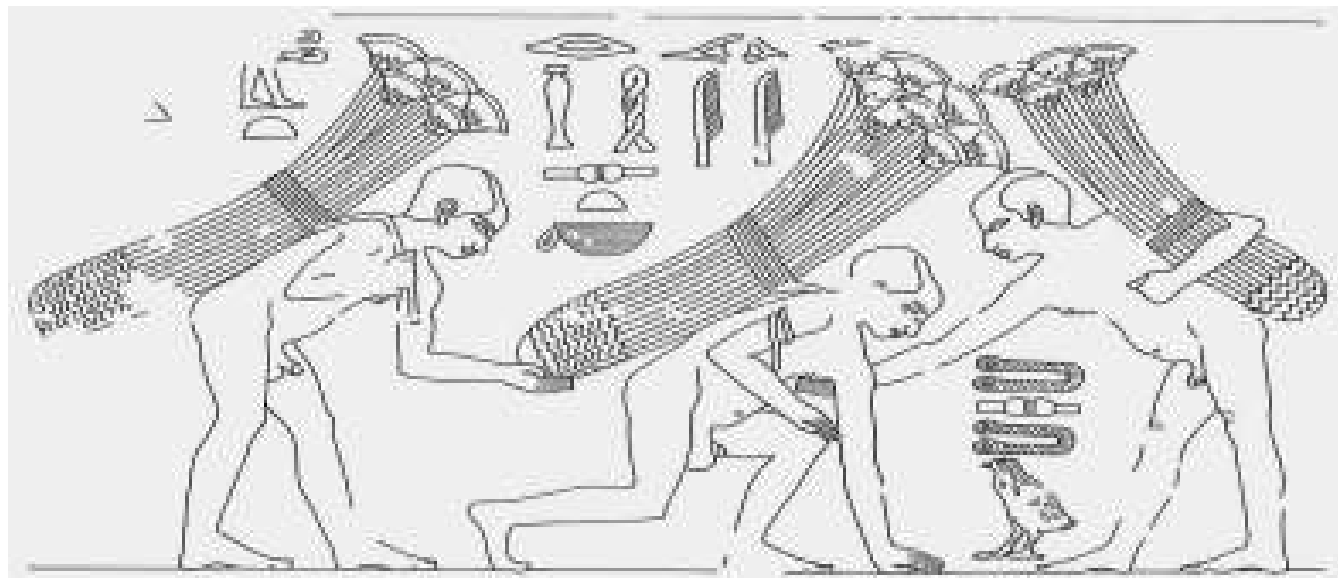

Fig.3: A papyrus carrier being helped by his mate, Tomb of $\mathrm{Ti}, 5^{\text {th }}$ Dynasty (Wild, Le Tombeau de Ti II,pl.cx). 


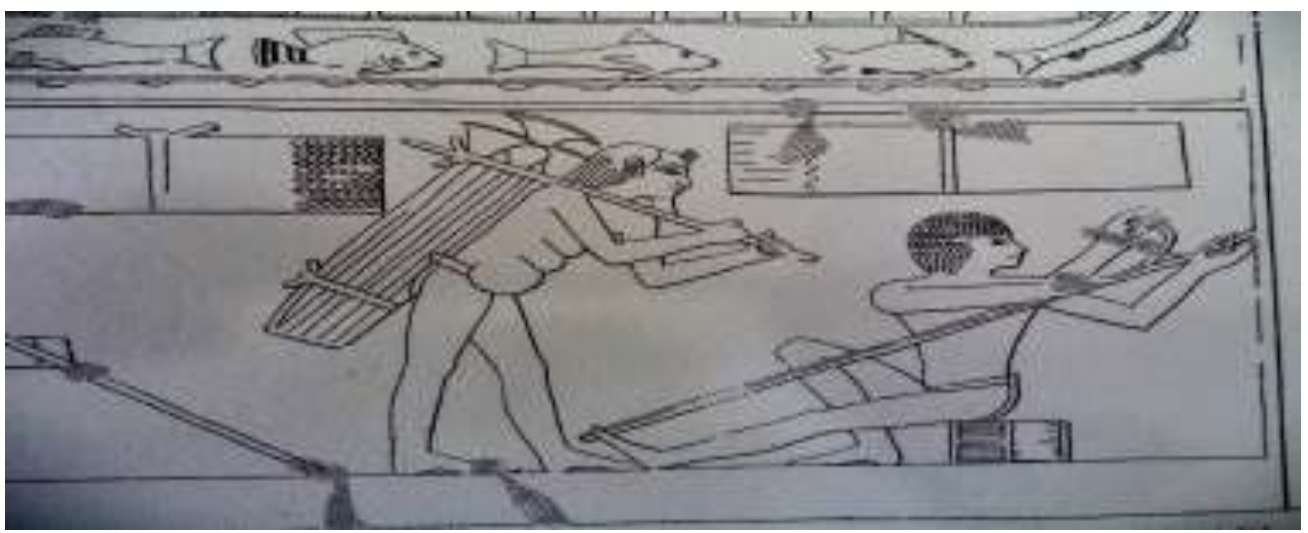

Fig. 4: a papyrus carrier from the tomb of Puyemra, $19^{\text {th }}$ Dynasty (Davies, theTomb of Puyemra, PI. XV)

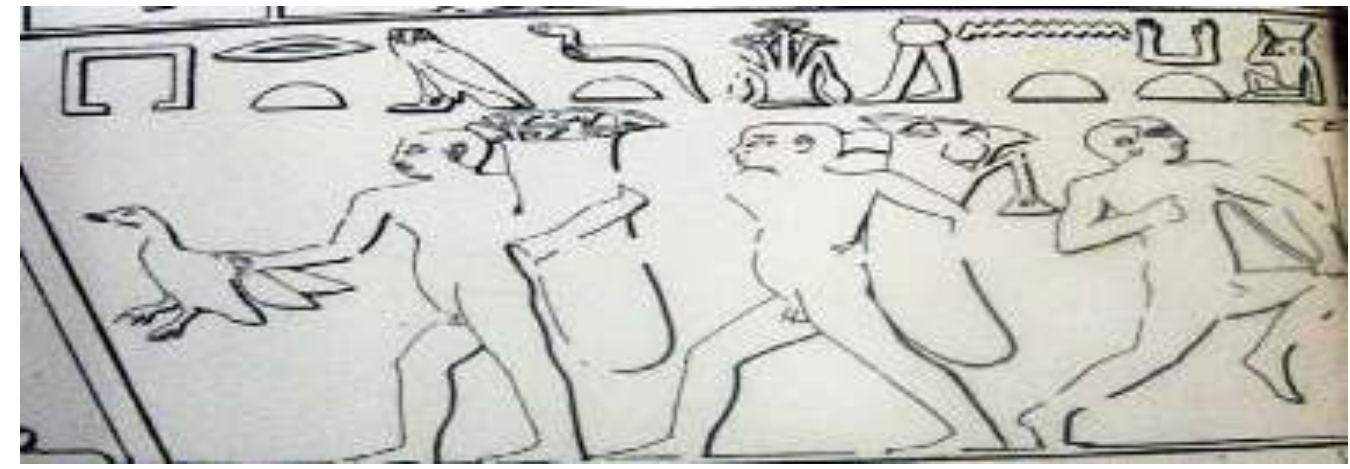

Fig. 5: Papyrus carrying with hands turned back, Tomb of Akhethotep, $5^{\text {th }}$ Dynasty (Davies, Ptahhotep and Akhethotep II, pl. xiii)

\section{Endnotes}

${ }^{1}$ Parkinson, H.; Quirke, S.; Wartenberg, U.; Leach, B. (1995) Papyrus, British Museum Press, London, p.12; Jourdan, F. (2001) "The Papyrus and its Origins" in: La Maat dans tous ses Etats; Cahiers Caribéens d'Égyptologie 2, p. 101-102; Kantor, H.J. (1960) Plant Ornament in Ancient Near East: A Case of Cultural Exchange, S.I., London, p.7

2 Nicholson, P.T.; Show, I. (2000), Ancient Egyptian Materials and Technology, Cambridge University Press, Cambridge, pp.228-229; Brewer, D.J.; Redford, D.B.; Redford, S. (1994), Domestic Plants and Animals: The Egyptian Origins, Aris \& Phillips, Warminster, p.40-41

${ }^{3}$ Nicholson; Show (2000), p.229

${ }^{4}$ Harpur, Y. (1987) Decorations in Egyptian Tombs of the Old Kingdom, Studies in Orientation and Scene Contents, Routledge \& Kegan Paul, London and New York, pp.149-151. Scenes of papyrus gathering and carriers in the Old Kingdom: OEE, 1.11 (1-35): www.oxfordexpeditiontoegypt.com

Some scenes are only fragments, thus the exact postures cannot be determined such as: the British Museum relief 451 (Hall, H. R.; Lambert (1922) Hieroglyphic texts from Egyptian stelae, \&c ., in the British Museum VI, British Museum, London, p.7, pl. 18)

${ }^{5}$ Blackman, A. (1915a), The Rock Tombs of Meir II, The Tomb- Chapel of Senbi's son of Ukhhotep (B-No.2), Egypt Exploration Fund, London, p.14, pls. III-IV, XXV, 2, XXVI, 1-2; Nicholson; Show (2000), p. 235, fig.9.4

${ }^{6}$ Two scenes representing only papyrus gathering from the Beni Hassan tombs of Khety and Baquet III on the top of the western wall. Newberry, P.E.(1893) Beni Hassan, Part II, K. Paul, Trench, Trübner, London, p.55-56; pl 11-12,15; Kanawati, N.; Woods, A. (2010) Beni Hassan, Art and Daily life in an Egyptian Province, Supreme Council of Antiquities, Cairo, p.50, fig.45; 42, fig.37 
${ }^{7}$ Blackman, A. (1915 b) The Rock Tombs of Meir III, The Tomb-chapel of Ukhhotep son of Ukhhotep and Mersi (B,No.4), Egypt Exploration Fund, London, p.12, pl. IV

${ }^{8}$ Vogelsang-Eastwood, G. (1993) Pharaonic Egyptian Clothing, E.J. Brill, New York, p.35-36

${ }^{9}$ McGill, S.M. (2005) " On the Use of weight belts" in: National Strength and Conditioning Association (NSCA) Hot Topic Series, March, p. 4

${ }^{10}$ R. F. E. Paget and A. A. Pirie (1898) The Tomb of Ptah-hetep, B. Quaritch, London, p.27, pl.XXXIII; Harpur (1987), p.151, figs.82, 103; Harpur, Y.; Scremin, P. (2008) Chapel of Ptahhotep, Scene Details, Oxford Expedition to Egypt, Oxford, p. 296, fig 115; Kanawati, N.; Woods, A. (2009) Artists in the Old Kingdom, Techniques and Achievements, Supreme Council of Antiquities, Cairo, p. 31, fig.24, top register.

${ }^{11}$ Davies, N. De G. (1901a) The Mastaba of Ptahhotep and Akhethotep at Saqqareh II. The Mastaba, The Sculptures of Akhethotep, K. Paul, Trench, Trübner, London, p.16, pl. XIII

12 Macramallah, R. (1935) Le Mastaba d'Idout, Impr. de l'Institut Français d'Archéologie Orientale, Le Caire, p.7, pls.VI-VII; Kanawati, N.; Abder-Raziq, M. (2003) The Unis Cemetery at Saqqara II, The Tombs of Iynefert and Ihy (reused by Idut), Australian Centre for Egyptology, Oxford, p. 47, pl.54

13 Hassan, S. (1975) Excavations at Saqqara, 1937-1938, Vol.1, The Mastaba on Neb-Kaw-Her, General Organization for Government Printing Office, Cairo, pp.35-36, pl. XXIV

${ }^{14}$ Moussa, A.F.; Junge, F. (1975) Two Tombs of Craftsmen, Mainz am Rhein, Verlag Philipp Von Zabern, p.40-41, pls. 11,13

${ }^{15}$ Breasted, J.H. (1936) Geschichte Aegyptens, Phaidon, Vienna, p.204

${ }^{16}$ Kanawati, N. (1983) The Rock Tombs of El-Hawawish, The Cemetery of Akhmim IV Macquarie Ancient History Association, Sydney, p.25, fig. 17

${ }^{17}$ Harpur (1987), p.150, 3

18 Blackman, (1915 b), pl. IV

19 Harpur and Scremin (2008), pl.114-115, fig.8, Moussa, A.M.; Altenmüller, Von H. (1971) The Tomb of Nefer and Ka-hay, Verlag Philipp von Zabren, Mainz am Rhein, pl.5

${ }^{20}$ Golet, O. (1993) "Nudity in Ancient Egypt" in: Notes in the History of Art, Vol.12, No. 2, Essays on Nudity in Antiquity in Memory of Otto Brendel, p. 21

${ }^{21}$ Davies (1901a), pl. XIII, Mouss; Altenmüller (1971), pl.5

${ }^{22}$ Simpson, W. M. (1992) The Offering Chapel of Kayemnofret in the Museum of Fine Arts, Boston Museum of Fine Arts, Boston, p.6, fig.6, pl.2 (a),3, 5 (a), pl.A; Hassan (1943), fig.77; Wild (1953), pl.LXXV, pl.CX; A. M. Moussa ; Altenmüller (1971), pl.5; Davies (1901 b), The Rock Tombs of Sheikh Saïd, pl.xii; Varielle (1938), fig.4; Petrie (1898), pl.v; Kanawati; Mcfalarne (1993), pls.8,33; Kanawati (1983), , fig.17; Davies (1922), pls. XV, XVI-XIX

${ }^{23}$ Blackman,A. (1953) The Rock Tombs of Meir, Part V, Egypt Exploration Fund, London, p. 37, pl. XXX, LX [2]; Harpur (1987), p.150-151, fig. 104

${ }^{24}$ Davies, N. De G. (1901b) The Rock Tombs of Sheikh Said, Offices of the Egypt Exploration Fund, London, pl.xii

${ }^{25}$ Wild, H. (1953) Le Tombeau de Ti, Facsicule II, La Chapelle, Partie II Impr. de l'Institut Français d'Archéologie Orientale, Le Caire, pl.Lxxv, pl.cx

${ }^{26}$ Lepsuis, C. R. (1913) Denkmäler aus Aegypten und Aethiopien. Ergänzungsband, Leipzig, xx; Brovarski, E. (2001) The Senedjemib Complex I, The Mastabas of Senedjemib Inti (G 2370), Khnumenti (G 2374) and Senedjemib Meht (G 2378), Art of the Ancient World, Museum of Fine Arts, Boston, p.44-45, fig.38

${ }^{27}$ Davies, N. De G. (1922) The Tomb of Puyemrê at Thebes I, The Metropolitan Museum of Fine Arts, New York, p.66, pls. XV, XVI-XIX

${ }^{28}$ Harpur (1987), p.150

${ }^{29}$ Hassan, S. (1943) Excavations Giza IV 1932-1933, Government Press, Cairo, p.135, fig.77

${ }^{30}$ Moussa; Altenmüller (1971), pl.5; Kanawati; Woods (2009), p.114 


\section{A Papyrus-Carrying Scene from the Tomb of Ukhhotep Son of Senbi (B 2) at Meir}

${ }^{31}$ Munro, P. (1995) Der Unas-Friedhof Nord-West, Topographisch-Historische, Das Doppelgrab der Koniginnen Nebet und Khenet, Verlag Philipp von Zabren, Mainz am Rhein, p.56,taf.11

32 Vachala, B. (2004) Abusir VIII, Die Relieffragmente aus der Mastaba des Ptahshepses in Abusir Czech Institute of Egyptology, Prague, p.132-133 [C639 (1349)]

${ }^{33}$ Davies, N. De G. (1901 b), pl.xii; Varille, A. (1938) Le Tombeau de Ni-Ankh-Pepi Á Zâouyet El-Mayetín, Impr. de l'Institut Français d'Archéologie Orientale, Le Caire, p.12, fig.4

${ }^{34}$ Davies, N. De. G. (1902) Deir El Gebrâwi I, Egypt Exploration Fund, London , pl.VI; Kanawati, N. (2007) Deir El-Gebrawi II, The Southern Cliffs, The Tomb of Ibi and others, Aris \& Philipps, Oxford, pl.68

${ }^{35}$ Kanawati, N. (1986) The Rock Tombs of El Hawawish, The Cemetery of Akhmim VI, Macquarie Ancient History Association, Sydney, fig. 14

${ }^{36}$ Borchardt, L. (1964) Denkmäler des Alten Reiches (Ausser dem Statuen) im Museum von Kairo, Nr. 1295- 1808, Teil II, Organisme Général, Cairo, p.163 (CG 1735)

${ }^{37}$ Blackman (1915 b), pl. IV

${ }^{38}$ Weeks, K.N. (1994) Mastabas of Cemetry G 600, including G 6010 (Neferbauptah); G 6020 (Iymery); 6030 (Ity); G 6040 (Shepseskaefankh), Museum of Fine Arts, Boston, p.41, fig.33

39 Roth, A.M. (1995) The Cemetry of Palace Attendants, Including G 2048-2099, G 2230+2231 and G 2240 , Museum of Fine Arts , Boston, p.101, pl.157

${ }^{40}$ Borchardt, L. (1907) Die Ausgrabungen Deutchen Orient-Gessellschaft in Abusir 1902-1904. Das Grabdnekmal des Kongis Ne-User-Re, Osnabrück Zeller, Leipzig, p.124, Abb.104 [b]

${ }^{41}$ Petrie, W.F. (1898) Deshasheh 1897, Egypt Exploration Fund, London, pl.v; Kanawati, N.; Mcfalarne, A. (1993) Deshasha, The Tombs of Inti, Shedu and others, The Australian Centre For Egyptology, Sydney, p. 28, pls.8,33

42 Petrie W. F.; Murray, M.A. (1952) Seven Memphite Tomb Chapels, British School of Egyptian Archaeology, London, p. 20, pl.viii [lower]; Harpur, Y. (1985) " The Identity and Positions of Relief Fragments" in: Journal of Egyptian Archaeology (JEA) 71, p. 37-38, fig.7

${ }^{43}$ Harpur; Scremin (2008), pls.116,117

${ }^{44}$ Hassan (1975), p.35-36, pl.XXIV

45 Altenmüller, Von H. (1998) Die Wanddarstellungen im Grab des Mehu im Saqqara, Verlag Philipp von Zabren, Mainz am Rhein, p.101, taf.14. The fifth figure is interestingly holding the bundle with both hands to pile it with other bundles that appears at the end of the scene

${ }^{46}$ Macramallah (1935), Le Mastaba d'Idout, 7, Pls.VI-VII; Kanawati, Abder-Raziq (2003), p. 47, pl.54

${ }^{47}$ Wild (1953), Le Tombeau de Ti II, pl.LXXV, pl.CX

${ }^{48}$ Roth (1995), p.101, pl.157

49 Davies (1901a), pl.xiii, fourth register, second figure from left

${ }^{50}$ Smith, W. S. (1946) A History of Egyptian Sculpture and Painting in the Old Kingdom, Oxford University Press, London, p.310

${ }^{51}$ Smith (1946), p.131, fig. 172

52 Davies, N. De G. (1905) The Rock-cut tombs of Amarna III, The Tombs of Huya and Ahmes, Egypt Exploration Fund, London, pl.VIII

${ }^{53}$ Blackman (1915a), pls. III-IV

${ }^{54}$ Kantor (1960), p.9

${ }^{55}$ Kanawati N.; Abder Raziq, M. (2004) Mereruka and his family I, The Tomb of Meryteti, Aris and Phillips, Oxford, pl.17, room C3

56 El-Khouli, A.; Kanawati, N. (1989), Quseir el-Amarna, Tombs of Pepy-ankh and Khemen-Wekh, Australian Centre for Egyptology, Sydney, p.47-48, pls.1[lower], 14, 37-38 


\section{مناظر لحمل نبات البردي من مقبرة اوخـ حتب ابن سنبي في مير}

استطاع المصريين القدماء استخدام البيئة المحيطة بهم و صوروا ذلك علي مقابر هم. ولقد مثل نبات البردي ـالذي كان ينمو بكثرة علي

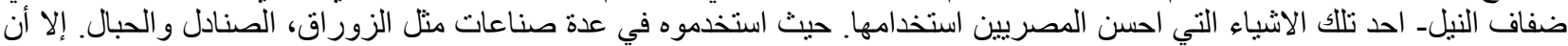

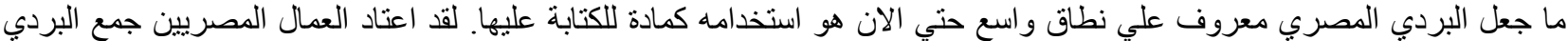

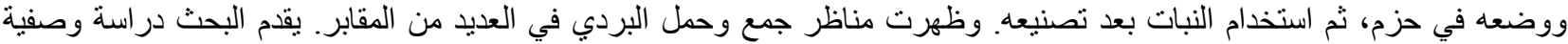

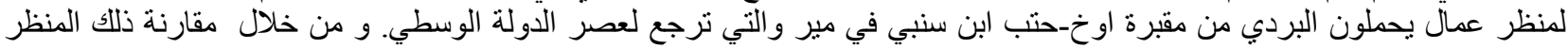

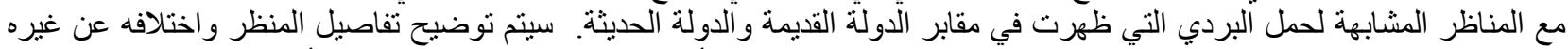

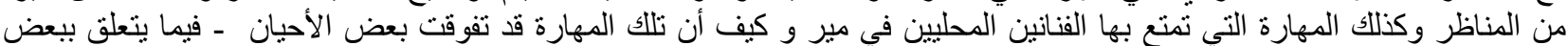

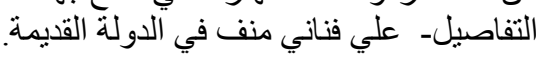

